\title{
Effect of Ethanolic Leaf Extract of Carica Papaya and Newbouldia Laevis on Hormone Profile of Alloxan-Induced Diabetic Wistar Rat
}

\author{
Ifegwu NO${ }^{1}$, Anibeze CIP ${ }^{2}$, Njoku-Oji NN ${ }^{3}$ \\ 1,2. Department of Anatomy, College of Medicine and Health Sciences, Abia State, University Uturu, Abia State, Nigeria. \\ ${ }^{3}$ Department of Human Physiology, Faculty of Basic Medical Sciences, Nnamdi, Azikiwe University, Nnewi Campus, Anambra \\ State, Nigeria. \\ Corresponding Author*
}

\begin{abstract}
Objective: This study was carried out to investigate the effect of ethanolic leaf extracts of $C$. papaya and $N$. laevis on hormone profile of alloxan-induced diabetic male wistar rats.

Methodology: Forty (40) male wistar rats weighing 150-180g were procured and acclimatized for two weeks, after which, they were divided into eight (8) groups of five (5) rats each, and were housed in cages. The groups were designated as groups $\mathbf{A}-\mathbf{H}$. Group A served as the control group, and received distilled water only. Animals in groups $\mathbf{B}-\mathbf{H}$ were induced with diabetes using alloxan. The diabetic group $B$ did not receive any treatment throughout the experiment, while the diabetic groups C - H received $400 \mathrm{mg} / \mathrm{kg}$ of $C$. papaya leaf extract, $600 \mathrm{mg} / \mathrm{kg}$ of C. papaya leaf extract, $400 \mathrm{mg} / \mathrm{kg}$ of $N$. laevis leaf extract, $600 \mathrm{mg} / \mathrm{kg}$ of $N$. laevis leaf extract, $200 \mathrm{mg} / \mathrm{kg}$ of $C$. papaya + $200 \mathrm{mg} / \mathrm{kg}$ of $N$. laevis, and $300 \mathrm{mg} / \mathrm{kg}$ of $C$. papaya $+300 \mathrm{mg} / \mathrm{kg}$ of $N$. laevis leaf extract respectively for 21 days through oral route with the aid of oral gastric tube. On the $22^{\text {nd }}$ day, the animals were sacrificed via chloroform inhalation and blood samples were then collected through ocular puncture for hormonal assay. All data were tabulated and statistically analyzed using SPSS version 25.0 .
\end{abstract}

Result: Levels of FSH, LH and Testosterone were significantly $(P<0.05)$ decreased in groups $B$ and $D$ when compared to the control group $A$; and significantly $(P<0.05)$ increased in groups F, G, and $H$ when compared to the control group A. However, there was no significant difference on the levels of FSH, LH and Testosterone in groups $\mathrm{C}$ and $\mathrm{E}$ when compared to the control group A.

Conclusion: Combined leaf extracts of Carica papaya and Newbouldia laevis have ameliorating effect on the levels of FSH, LH and Testosterone of alloxan-induced male wistar rats.

Keywords: Carica papaya, Newbouldia laevis, FSH, LH, Testosterone

\section{INTRODUCTION}

A bout 422 million people worldwide have diabetes, with majority living in low-and middle-income countries, 1.5 million deaths are directly attributed to diabetes each year, and both the number of cases and the prevalence of diabetes have been steadily increasing over the past few decades ${ }^{[1]}$. Diabetes is a chronic, metabolic disease characterized by elevated levels of blood glucose (or blood sugar), which leads over time to serious damage to the heart, blood vessels, eyes, kidneys and nerves ${ }^{[1]}$. The most common is type 2 diabetes, usually in adults, which occurs when the body becomes resistant to insulin or does not make enough insulin ${ }^{[1]}$. In the past three decades the prevalence of type 2 diabetes has risen dramatically in countries of all income levels; and Type 1 diabetes, once known as juvenile diabetes or insulindependent diabetes, is a chronic condition in which the pancreas produces little or no insulin by itself ${ }^{[1]}$. For people living with diabetes, access to affordable treatment, including insulin, is critical to their survival and there is a globally agreed target to halt the rise in diabetes and obesity by 2025 [1]

Diabetic men have significantly low serum testosterone with low LH and FSH, hypercholesterolemia, hypertriglyceridemia, hypoalbuminemia and increased oxidative stress ${ }^{[2]}$. Low serum testosterone in diabetic men is accompanied by low LH and FSH due to the inability of the pituitary gland to respond appropriately to a decline in testosterone implying central effect of high serum glucose on the interaction between the nervous and endocrine system. Nutritional deficiency, increased oxidative stress and increased aromatase activity due to excessive body fat could also have contributed to the low serum testosterone ${ }^{[2]}$. An important complication of diabetes mellitus is the disturbance in the male reproductive system ${ }^{[3]}$. Glucose metabolism is an important event in spermatogenesis. Diabetes mellitus induces molecular alterations which negatively affect sperm quality and function as well as fertility ${ }^{[4]}$. Many studies in both human and animal studies have confirmed the deleterious effect of diabetes mellitus on sexual functions such as; semen parameters, nuclear DNA fragment and chromatin quality ${ }^{[5,6]}$. The main goal of diabetes treatment is establishing of normal blood glucose and preventing or delaying its metabolic complications. Medicinal plants which are composed of phytochemicals and phytonutrients, possess therapeutic properties, or exert beneficial pharmacological effect on the human body and animal body; and include such plants such as Carica papaya and Newbuldia laevis that could help to improve the health of diseased living organisms. 
C. papaya which is commonly known as pawpaw, belongs to the family Caricaceae. It originated from Southern Mexico, Central America and the northern part of South America; and is now being cultivated in many tropical countries such as India, Bangladesh, Indonesia, Sri Lanka, Philippines, West Indies, Malaysia and Africa. Its leaves, barks, roots, latex, fruit, flowers, and seeds are used in folk medicine to treat varieties of diseases ${ }^{[7]}$. Its constituents such as vitamins, including $\mathrm{A}, \mathrm{E}$ and $\mathrm{C}$ are rich source of antioxidant and minerals such as magnesium and potassium, vitamin B pantothenic acid and folate and fiber ${ }^{[8]}$. Phytochemical analysis of its leaf revealed saponins, cardiac glycosides, and alkaloids ${ }^{[9]}$, trace amount of chlorogenic acid, flavonoids and coumarin compounds ${ }^{[10]}$. Studies have reported the antidiabetic potential of its seeds and leaves' extract ${ }^{[11,12]}$. Its leaf has been proven to have antidiabetic effect ${ }^{[13]}$, hypoglycemic properties [14], antioxidant, immunomodulatory, and hypolipidemic effects ${ }^{[15]}$, helpful in preventing diabetic complications by dyslipidemia improvement ${ }^{[16]}$ and exhibits anti-inflammatory effect ${ }^{[17]}$.

$N$. laevis which belongs to the family Bignoniaceae is a nonleguminous, medium sized angiosperm, commonly called boundary tree (planted as hedgerows and as a life fence), chieftaincy tree (used in chieftaincy and traditional religious ceremonies) ${ }^{[18]}$, or tree of life (possibly because of its longevity). Different local names of the plant are Ogirisi (Igbo), Akoko (Yoruba), Aduruku (Hausa) ${ }^{[19]}$. It is a plant with diverse claims of effectiveness, widely utilized in traditional medicine by various cultures throughout the tropical Africa, including but not limited to Nigeria, Togo, Senegal, Ghana, Congo, Cote de Voire, and Cameroun. Usman and Osuji, [20] reported that the phytochemical composition of the flower and leaves of N.laevis include cardiac and steroidal glycosides, flavonoids and tannins. In Nigeria, its bark is chewed and swallowed for stomach pains, diarrhea and toothache ${ }^{[21]}$. The plant is useful for ear ache, sore feet, chest pain, epilepsy and convulsion in children ${ }^{[22]}$. It is employed in the treatment of coughs, diarrhoea and dysentery and is also given to children for treating epilepsy and convulsions ${ }^{[23]}$. Other medical uses include folk treatment of fevers (including yellow fever), malaria, stomach ache, cough, sexually transmitted infections, skin infections, tooth ache, breast cancer, constipation, pain (pelvic pain in females, chest pain, ear ache), gonococcal orchitis, elephantiasis, sorefeet, ulcer, epilepsy, convulsion, migraine, sickle cell anaemia, as a febrifuge, as a vermifuge, in female reproductive healthcare (fibroids, infertility, hemorrhage), as aphrodisiacs, eye problems, snake bites, wound healing, diabetes, arthritis, rheumatism and other inflammatory

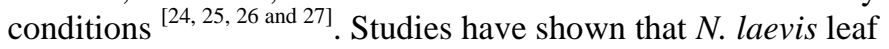
is used to manage hyperglycemia, improve haematological and biochemical derangements, control muscle wasting, induce adipogenesis ${ }^{[28]}$, has antidiabetic effect ${ }^{[29]}$, exhibits antioxidant and free radical scavenging, antimicrobial and anti-malarial ${ }^{[30]}$, sedative and anticonvulsant ${ }^{[31]}$, analgesic, antinociceptive and an-tiinflamatory ${ }^{[32]}$, hepatoprotective ${ }^{[33,}$
${ }^{34]}$, anticancer [35], wound healing and antiulcer [36], hypoglycemic ${ }^{[28]}$ activities among others.

Hence this study was carried out to investigate on the combined effect leaf extracts of $C$. papaya and $N$. laevis on the serum hormonal levels of alloxan-induced diabetic male wistar rats since no work has been carried out on this.

\section{MATERIALS AND METHODS}

\subsection{Animal procurement, care and treatment}

Forty (40) male wistar rats weighing between $130 \mathrm{~g}$ to $180 \mathrm{~g}$ were procured and housed at the Animal house of Anatomy Department, Abia State University; Uturu with wire gauze cages in a well-ventilated area, were maintained under standard laboratory conditions of temperature $\left(22+2^{0} \mathrm{C}\right)$, relative humidity (55-65\%) and 12 hours light/dark cycle. They were fed with standard commercial pellet diet and water ad libitum and were also acclimatized for two weeks before the experiment. Their health statuses were closely monitored before and during the experiment. All procedures were carried out in strict accordance with the Institutional guidelines on the care and use of experimental animals.

\subsection{Collection, identification and preparation of plant material}

Fresh leaves of $C$. papaya and $N$. lavis leaves were plucked from Nkporo in Ohafia L.G.A., Abia State, and were authenticated at Herbarium unit, Botany Department, Abia State University, Uturu, Abia State. The leaves were air dried and crushed using laboratory blender. Extractions were done using ethanol. The crude ethanol extracts were kept in an airtight container and stored in a refrigerator at $4^{\circ} \mathrm{C}$ until time of use. At the time of use, the ethanol extracts were filtered into a stainless basin with a white cloth and placed in a water bath so as to dry up the ethanol. $250 \mathrm{mg}$ of these extracts $/ \mathrm{kg}$ body weight were dissolved in $10 \mathrm{mls}$ of distilled water and were administered to the animals.

\subsection{Induction of diabetes}

The rats were divided into non-diabetic control group and experimental groups. The baseline blood glucose level of the experimental group to be inducted was determined before the induction of diabetes. The rats were allowed to fast over night prior to injection of alloxan and diabetes was induced by intra-peritoneal administration of $150 \mathrm{mg}$ of alloxan per $\mathrm{kg}$ body weight of rat $\left(150 \mathrm{mg} / \mathrm{kg}\right.$ body weight ${ }^{[37]}$. After the induction, the rats were allowed to have free access to the same feed and water. After 72 hours, blood samples obtained through tail tip puncture of the rats were used to confirm diabetes in the rats by testing for hyperglycemia using Glucometer. Diabetes was confirmed at fasting blood glucose levels greater than $200 \mathrm{mg} / \mathrm{dl}^{[38]}$.

\subsection{Experimental protocol}

The animals were grouped into eight (8) groups of five (5) rats each. Different doses of the leaf extracts were administered via oral route with the aid of oral gastric tube as shown below: 
Group A The control group + distilled water.

Group B

Diabetic group + No treatment

Group C

Diabetic $+400 \mathrm{mg} / \mathrm{kg}$ of C. papay leaf extract.

Group D

Group E

Diabetic $+600 \mathrm{mg} / \mathrm{kg}$ of $C$. papay leaf extract.

Diabetic $+400 \mathrm{mg} / \mathrm{kg}$ of $N$. laevis leaf extract.

Group F

Diabetic $+600 \mathrm{mg} / \mathrm{kg}$ of $N$. laevis leaf extract.

\section{Group G}

Diabetic $+200 \mathrm{mg} / \mathrm{kg}$ of $C$. papaya and $200 \mathrm{mg} / \mathrm{kg}$ of $N$. laevis leaf extracts.

Group H

Diabetic $+300 \mathrm{mg} / \mathrm{kg}$ of $C$. papaya and $300 \mathrm{mg} / \mathrm{kg}$ of $N$. laevis leaf extracts.

\subsection{Sample collection}

The extracts were administered for twenty one (21) days. On the $22^{\text {nd }}$ day, blood samples were collected through ocular puncture as described by Hoff and Rlagt, ${ }^{[39]}$ for hormonal assay. The obtained blood samples were spun at $2500 \mathrm{pm}$ for $10 \mathrm{~min}$ using wisperfuge model 1384 centrifuge at $10-25^{\circ} \mathrm{C}$, serum samples were collected, refrigerated and assayed for growth hormone, follicle stimulating hormone, testosterone and luteinizing hormone using the microwell enzyme linked immunoassay (ELISA) technique, and analytical grade reagent (Syntron Bioresearch Inc, USA).

\subsection{Statistical Analysis}

All data were tabulated and statistically analyzed using SPSS version 25.0. Results were expressed as Mean \pm standard error of mean (SEM). Comparative analysis amongst groups was done using one-way analysis of variance (ANOVA). A posthoc analysis using Bonferoni multiple comparative tests was performed to identify significant groups. $\mathrm{P}<0.05$ was taken as statistically significant.

\section{RESULTS}

Table 3.1: A table showing the effect of ethanolic leaf extracts of $C$. papaya and $N$. laevis on serum levels of follicle stimulating hormone (FSH) of alloxan induced diabetic wistar rats.

\begin{tabular}{|c|c|c|}
\hline Groups & Dosage of aqueous extracts & FSH $(\mathrm{IU} / \mathrm{mL})$ \\
\hline A & Control (Distilled water) & $3.71 \pm 0.14$ \\
\hline B & Diabetic (Distilled water) & $2.70 \pm 0.12^{*}$ \\
\hline C & $400 \mathrm{mg} / \mathrm{kg}$ C. papaya & $3.15 \pm 0.26$ \\
\hline D & $600 \mathrm{mg} / \mathrm{kg}$ C. papaya & $2.20 \pm 0.17^{*}$ \\
\hline E & $400 \mathrm{mg} / \mathrm{kg}$ N. laevis & $3.98 \pm 0.17$ \\
\hline F & $600 \mathrm{mg} / \mathrm{kg}$ N. laevis & $4.68 \pm 0.14^{*}$ \\
\hline G & $\begin{array}{c}200 \mathrm{mg} / \mathrm{kg} \text { C. papaya }+ \\
200 \mathrm{mg} / \mathrm{kg} \text { N. laevis }\end{array}$ & $4.89 \pm 0.20^{*}$ \\
\hline H & $\begin{array}{c}300 \mathrm{mg} / \mathrm{kg} \text { C. papaya }+ \\
300 \mathrm{mg} / \mathrm{kg} \text { N. laevis }\end{array}$ & 4.20 \\
\hline
\end{tabular}

Table 3.1 showed a significant decrease $(\mathrm{P}<0.05)$ on the serum FSH levels in group B that received no treatment and group D that received $600 \mathrm{mg} / \mathrm{kg}$ of C. papaya when compared to the control group A; and a significant increase $(\mathrm{P}<0.05)$ on the serum FSH level in groups $\mathrm{F}, \mathrm{G}$ and $\mathrm{H}$ that received $600 \mathrm{mg} / \mathrm{kg}$ of $N$. laevis, $200 \mathrm{mg} / \mathrm{kg}$ of C. papaya $+200 \mathrm{mg} / \mathrm{kg}$ of $N$. laevis, and $300 \mathrm{mg} / \mathrm{kg}$ of C. papaya $+300 \mathrm{mg} / \mathrm{kg}$ of $N$. laevis respectively when compared with the control group A. However, there was no significant difference $(\mathrm{P}>0.05)$ on the serum FSH levels in groups $\mathrm{C}$ and $\mathrm{E}$ that received $400 \mathrm{mg} / \mathrm{kg}$ of $C$. papaya, and $400 \mathrm{mg} / \mathrm{kg} N$. laevis respectively when compared with the control group A.

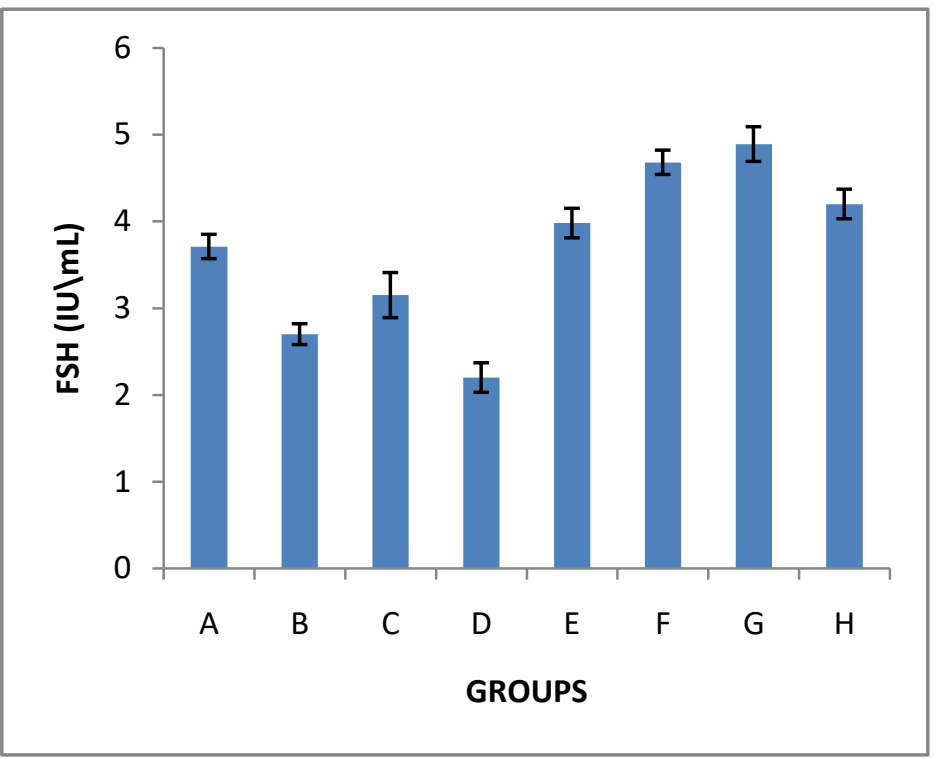

Figure 3.1: The effect of ethanolic leaf extracts of C. papaya and $N$. laevis on serum levels of follicle stimulating hormone (FSH) of alloxan induced diabetic wistar rats.

Table 3.2: A table showing the effect of ethanolic leaf extracts of $C$. papaya and $N$. laevis on serum levels of luteinizing hormone (LH) of alloxan induced diabetic wistar rats.

\begin{tabular}{|c|c|c|}
\hline Groups & Dosage of aqueous extracts & LH (IU/L) \\
\hline A & Control (Distilled water) & $3.64 \pm 0.08$ \\
\hline B & Diabetic (Distilled water) & $2.17 \pm 0.35^{*}$ \\
\hline C & $400 \mathrm{mg} / \mathrm{kg}$ C. papaya & $3.09 \pm 0.20$ \\
\hline D & $600 \mathrm{mg} / \mathrm{kg}$ C. papaya & $2.22 \pm 0.19^{*}$ \\
\hline E & $400 \mathrm{mg} / \mathrm{kg}$ N. laevis & $4.04 \pm 0.22$ \\
\hline F & $600 \mathrm{mg} / \mathrm{kg}$ N. laevis & $4.65 \pm 0.09^{*}$ \\
\hline G & $\begin{array}{r}200 \mathrm{mg} / \mathrm{kg} \text { C. papaya }+ \\
200 \mathrm{mg} / \mathrm{kg} \text { N. laevis }\end{array}$ & $4.80 \pm 0.26^{*}$ \\
\hline H & $\begin{array}{r}300 \mathrm{mg} / \mathrm{kg} \mathrm{C.} \mathrm{papaya}+ \\
300 \mathrm{mg} / \mathrm{kg} \text { N. laevis }\end{array}$ & $4.18 \pm 0.21^{*}$ \\
\hline
\end{tabular}

Table 3.2 showed a significant decrease $(\mathrm{P}<0.05)$ on the serum LH levels in group B that received no treatment and group D that received $600 \mathrm{mg} / \mathrm{kg}$ of C. papaya when compared to the control group $\mathrm{A}$; and a significant increase $(\mathrm{P}<0.05)$ on the serum $\mathrm{LH}$ level in groups $\mathrm{F}, \mathrm{G}$ and $\mathrm{H}$ that received 
$600 \mathrm{mg} / \mathrm{kg}$ of $N$. laevis, $200 \mathrm{mg} / \mathrm{kg}$ of C. papaya $+200 \mathrm{mg} / \mathrm{kg}$ of $N$. laevis, and $300 \mathrm{mg} / \mathrm{kg}$ of C. papaya $+300 \mathrm{mg} / \mathrm{kg}$ of $N$. laevis respectively when compared with the control group A. However, there was no significant difference $(\mathrm{P}>0.05)$ on the serum LH levels in groups $\mathrm{C}$ and $\mathrm{E}$ that received $400 \mathrm{mg} / \mathrm{kg}$ of C. papaya, and $400 \mathrm{mg} / \mathrm{kg} N$. laevis respectively when compared with the control group A.

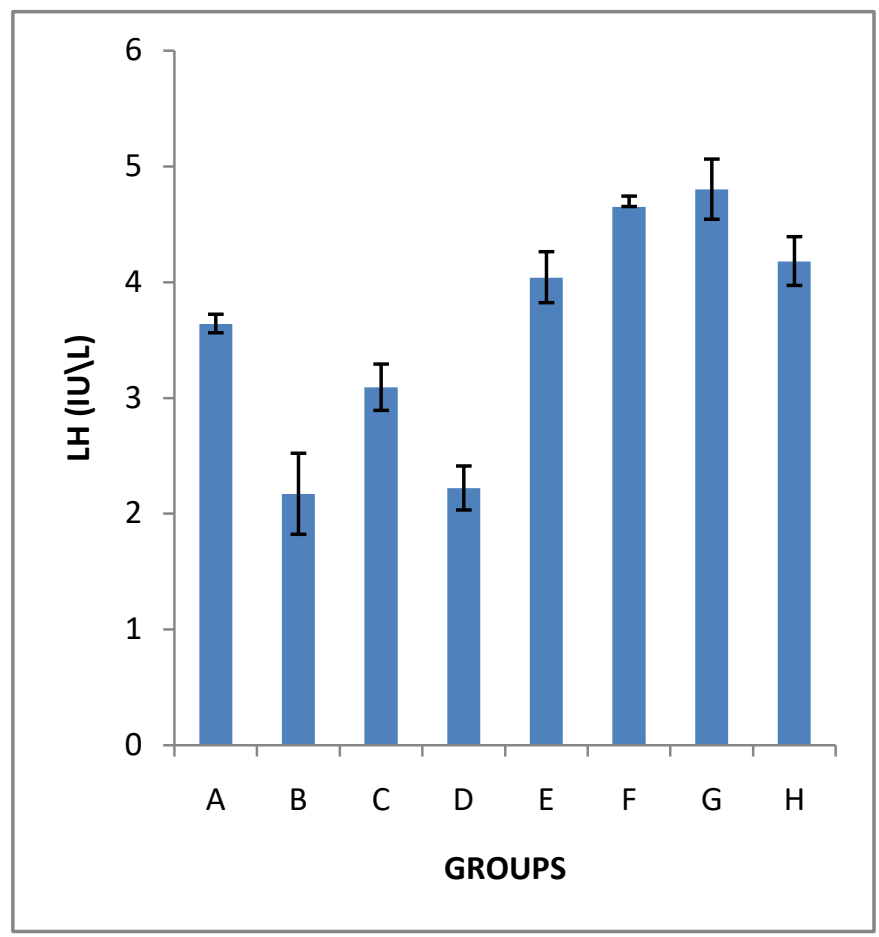

Figure 3.2: The effect of ethanolic leaf extracts of C. papaya and N. laevis on serum levels of luteinizing hormone (LH) of alloxan induced diabetic wistar rats.

Table 3.3: A table showing the effect of ethanolic leaf extracts of $C$. papaya and $N$. laevis on serum levels of testosterone of alloxan induced diabetic wistar rats.

\begin{tabular}{|c|c|c|}
\hline Groups & Dosage of aqueous extracts & $\begin{array}{c}\text { Testosterone } \\
(\mathrm{ng} / \mathrm{dl})\end{array}$ \\
\hline $\mathrm{A}$ & Control (Distilled water) & $3.38 \pm 0.19$ \\
\hline $\mathrm{B}$ & Diabetic (Distilled water) & $2.18 \pm 0.17^{*}$ \\
\hline $\mathrm{C}$ & $400 \mathrm{mg} / \mathrm{kg}$ C. papaya & $3.17 \pm 0.20$ \\
\hline $\mathrm{D}$ & $600 \mathrm{mg} / \mathrm{kg}$ C. papaya & $2.3 \pm 0.20^{*}$ \\
\hline $\mathrm{E}$ & $400 \mathrm{mg} / \mathrm{kg}$ N. laevis & $3.66 \pm 0.23$ \\
\hline $\mathrm{F}$ & $600 \mathrm{mg} / \mathrm{kg}$ N. laevis & $4.34 \pm 0.48^{*}$ \\
\hline $\mathrm{G}$ & $\begin{array}{c}200 \mathrm{mg} / \mathrm{kg} \text { C. papaya }+ \\
200 \mathrm{mg} / \mathrm{kg} \text { N. laevis }\end{array}$ & $4.85 \pm 0.16^{*}$ \\
\hline $\mathrm{H}$ & $\begin{array}{c}300 \mathrm{mg} / \mathrm{kg} \text { C. papaya }+ \\
300 \mathrm{mg} / \mathrm{kg} \text { N. laevis }\end{array}$ & $4.16 \pm 0.26^{*}$ \\
\hline
\end{tabular}

Table 3.3 showed a significant decrease $(\mathrm{P}<0.05)$ on the serum testosterone levels in group $\mathrm{B}$ that received no treatment and group D that received $600 \mathrm{mg} / \mathrm{kg}$ of C. papaya when compared to the control group A; and a significant increase $(\mathrm{P}<0.05)$ on the serum testosterone level in groups $\mathrm{F}, \mathrm{G}$ and $\mathrm{H}$ that received $600 \mathrm{mg} / \mathrm{kg}$ of $N$. laevis, $200 \mathrm{mg} / \mathrm{kg}$ of C. papaya $+200 \mathrm{mg} / \mathrm{kg}$ of $N$. laevis, and $300 \mathrm{mg} / \mathrm{kg}$ of $C$. papaya $+300 \mathrm{mg} / \mathrm{kg}$ of $N$. laevis respectively when compared with the control group A. However, there was no significant difference $(\mathrm{P}>0.05)$ on the serum testosterone levels in groups $\mathrm{C}$ and $\mathrm{E}$ that received $400 \mathrm{mg} / \mathrm{kg}$ of C. papaya, and $400 \mathrm{mg} / \mathrm{kg}$ $N$. laevis respectively when compared with the control group A.

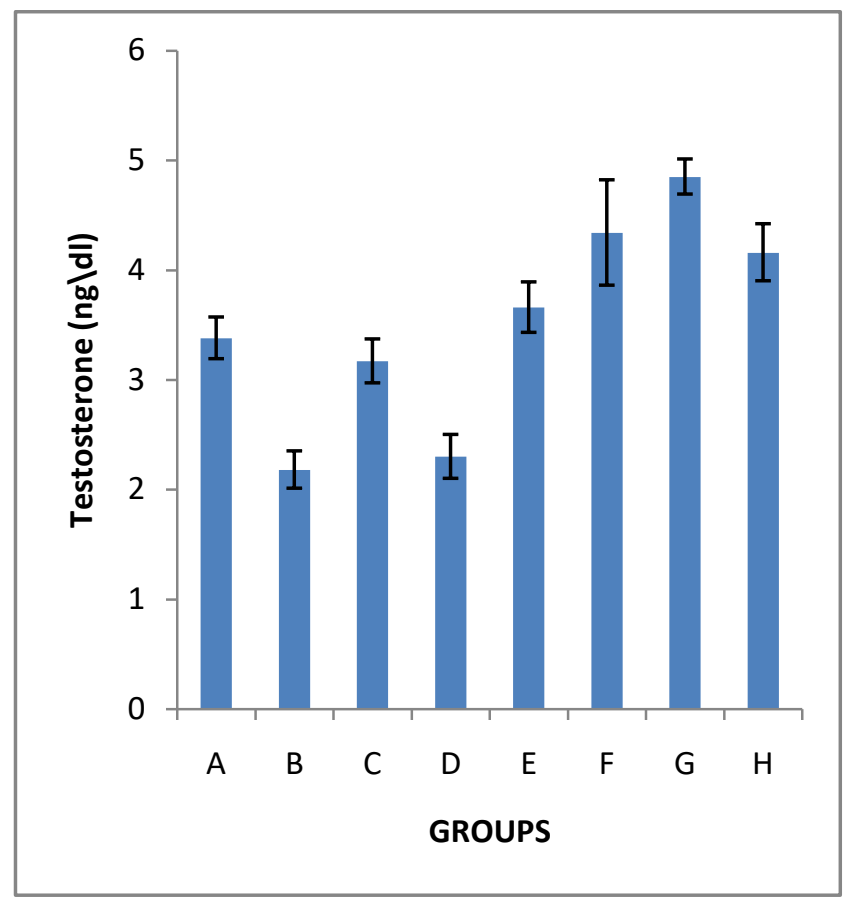

Figure 3.3: The effect of ethanolic leaf extracts of C. papaya and N. laevis on serum levels of testosterone of alloxan induced diabetic wistar rats.

\section{IV.DISCUSSION}

Reproductive complications such as disruption of male fertility, impotence, retrograde ejaculation and hypogonadism due to damage to the beta cells of the pancreas which secret pancreatic insulin that regulate the male hypothalamicpituitary-gonadal axis which is essential for fertility also occur due DM complication ${ }^{[4,40, \text { and } 41]}$. The onset of Type I diabetes is known to disrupt the HPG axis, resulting in impaired spermatogenesis and subsequent sub-fertility and disruptions in any part of the HPG axis impair fertility ${ }^{[42]}$. Thus this research work was undertaken to investigate the effect of ethanolic leaf extracts of $C$. papaya and $N$. laevis on the serum hormonal levels of alloxan-induced diabetic male wistar rats.

The significant decrease $(\mathrm{P}<0.05)$ on the serum hormonal levels of FSH., LH and testosterone in group B that received no treatment when compared to the control group A in tables 3.1, 3.2 and 3.3 could be due to the effect of diabetes. Research has shown that the induced-alloxan selectively kills the insulin-producing beta-cells found in the pancreas as alloxan is proven to induce diabetes in laboratory animals ${ }^{[43}$, ${ }^{44]}$. This occurs most likely because of selective uptake of the compound due to its structural similarity to glucose as well as 
the beta-cell's highly efficient uptake mechanism (GLUT2). In addition, alloxan has a high affinity to SH-containing cellular compounds and, as a result, reduces glutathione content. Furthermore, alloxan inhibits glucokinase, a SH-containing protein essential for insulin secretion induced by glucose ${ }^{[37]}$. Research has shown that diabetic men had significantly low serum testosterone with low LH and FSH, hypercholesterolemia, hypertriglyceridemia, hypoalbuminemia and increased oxidative stress ${ }^{[2]}$. Research has also shown that there exist a link between diabetes and low testosterone, men with diabetes are more likely to have low testosterone; and men with low testosterone are more likely to later develop diabetes ${ }^{[45]}$. Testosterone helps the body's tissues take up more blood sugar in response to insulin, men with low testosterone more often have insulin resistance and need to produce more insulin to keep blood sugar normal ${ }^{[45]}$. According to Schoeller $\mathrm{el} \mathrm{al.},{ }^{[41]}$, in a normally functioning hypothalamic pituitary gonadal axis, the hypothalamus releases GnRH pulses that stimulate the pituitary to secrete both luteinizing hormone (LH) and follicular stimulating hormone (FSH). LH and FSH act on the Sertoli cells and the Leydig cells, respectively, to stimulate the process of spermatogenesis. The onset of Type I diabetes is known to disrupt the HPG axis, resulting in impaired spermatogenesis and subsequent subfertility, thus disruptions in any part of the HPG axis impair fertility ${ }^{[41]}$. Also serum insulin has long been known to affect the central nervous system, and these effects could mediate whole body energy homeostasis, including the reproductive axis through further signaling to the pituitary and ultimately, the gonads ${ }^{[41]}$. Research has also revealed that the peripheral insulin injection caused an increase in insulin levels in cerebral spinal fluids, suggesting that insulin could potentially be a signal to the brain regarding energy stores and promoting whole-body energy homeostasis ${ }^{[46]}$. A lack of insulin would signal to the brain a lack of energy supply and the central nervous system could potentially shut down extraneous energy-consuming processes such as reproductive function [41]. Indeed, insulin levels have dramatic effects on the regulation of the HPG axis. The effects of diabetes on the reproductive axis are mediated at least in part, by signaling in the brain. Insulin mediates its effects through binding with the insulin receptor, resulting in a signaling cascade.

The result of significant decrease $(\mathrm{P}<0.05)$ on the serum hormonal levels of FSH, LH and testosterone in group D of tables $3.1,3.2$ and 3.3 that received $600 \mathrm{mg} / \mathrm{kg}$ of $C$. papaya when compared to the control group A may be due to antifertility effect of $C$. papaya when taken at a higher dose of $600 \mathrm{mg} / \mathrm{kg}$. Research has revealed that C. papaya leaf possesses anti-fertility properties, and could be used to control birth rate ${ }^{[47]}$. The exact mechanism by which the leaf extract reduce sperm count is not known, but it has been suggested that "papain" one of its components, could have crossed the blood testes barrier to exert harmful effects on the seminiferous tubules of the testes ${ }^{[48]}$ thereby leading to decrease in the level of testicular apparatus. It has been revealed that many bioactive as well as toxic agents of plant extracts can affect the regulation of conception and reproduction ${ }^{[49,50]}$. Also, bioactive agents such as alkaloids and flavonoids have been shown to reduce plasma concentrations of some fertility hormones ${ }^{[51,52]}$. Thus, the presence of these phytochemicals in the leaf extract could have accounted for the alterations in the levels serum hormones in this study.

Then the significant increase $(\mathrm{P}<0.05)$ on the serum hormone levels of FSH, LH and testosterone in groups F, G and $\mathrm{H}$ that received $600 \mathrm{mg} / \mathrm{kg}$ of $N$. laevis, $200 \mathrm{mg} / \mathrm{kg}$ of C. papaya + $200 \mathrm{mg} / \mathrm{kg}$ of $N$. laevis, and $300 \mathrm{mg} / \mathrm{kg}$ of C. papaya + $300 \mathrm{mg} / \mathrm{kg}$ of $N$. laevis respectively when compared with the control group A could be due to the ameliorating effect of the combined leaf extracts $C$. papaya and $N$. laevis at low dosages, and that of $N$. laevis to the testicular cells (leydig and sertolily cells). According to Schoeller el al., ${ }^{[42], ~ i n ~ a ~}$ normally functioning hypothalamic pituitary gonadal axis, the hypothalamus releases GnRH pulses that stimulate the pituitary to secrete both luteinizing hormone (LH) and follicular stimulating hormone (FSH). LH and FSH act on the Sertoli cells and the Leydig cells, respectively, to stimulate the process of spermatogenesis, thus the significant increased in the hormonal levels in groups $\mathrm{F}, \mathrm{G}$ and $\mathrm{H}$; and also the increase in groups $\mathrm{C}$ and $\mathrm{E}$ though not significant (figures 3.1, 3.2 and 3.3). Aqueous leaf extracts of $N$. laevis can be used to manage hepatotoxicity and testicular toxicity [53], exhibits protective effect on testicular damage ${ }^{[54]}$, prevent oxidative stress in testes and improve fertility outcomes ${ }^{[52]}$ and improve erectile function ${ }^{[55]}$. Newbouldia laevis can also boost the FSH and LH levels ${ }^{[56]}$.

\section{CONCLUSION}

Carica papaya and Newbouldia laevis leaf extracts have ameliorating effect on serum levels of FSH, LH and testosterone, and the ameliorating effect of the combined doses to the parameters were better at lower dosages than when the individual leaf extracts were administered to the diabetic wistar rats. Thus, the use of the leaf extracts of $C$. papaya and $N$. laevis in the treatment of diabetics should be encouraged, especially in the combined form because of their ameliorating effect to DM and complications associated with it.

Funding: No funding sources

Conflict of interest: None declared.

Ethical Approval: Approved by Institutional ethical approval.

\section{REFERENCES}

[1] World Health Organisation. Diabetes, https://www.who.int/health-topics/diabetes\#tab=tab_1

[2] Mailankot Maneesh, Jayalakshmi H, Singh T, Chakrabarti Amit. Impaired hypothalamic-pituitary-gonadal axis function in men with diabetes mellitus. Indian journal of clinical biochemistry. 2006; 21. 165-8.

[3] Njoku-Oji NN, Ifegwu NO, Umahi GO, Sobanke AO, Uchefuna RC. Beneficial effects of ethanolic seed extract of Cyperus esculentus on bloodglucose and sperm quality in alloxan-induced 
diabetic rats. IOSR Journal of Pharmacy and Biological Sciences. 2019; 14(1): 84-90.

[4] Mallidis C, Agbaje I, McClure N, Kliesch S (2011). The influence of diabetes mellitus on male reproductive function: a poorly investigated aspect of male infertility. Urologe A. 50: 33-37.

[5] Agbaje IM, Rogers DA, McVicar CM, McClure N, Atkinson AB, Mallidis C, Lewis SE. Insulin dependant diabetes mellitus: implications for male reproductive function. Hum Reprod. 2007; (22): $1871-1877$.

[6] Kilarkaje N, Al-hussaini H, Al-Bader M. Diabetes-induced DNA damage and apoptosis are associated with poly (ADP ribose) polymerase 1 inhibition in rat testis. Eur. J. Pharmacol. 2014; (734): 29-40.

[7] Jaiswal P, Kumar P, Singh VK, Singh DK. Carica papaya linn: a potential source for various health problems. J Pharm Res. 2010; (3): 998-1003.

[8] Vij T and Prasha Y. (2015). A review on medicinal properties of Carica papaya Linn. Asian Pac J Trop Dis. 2015; (5): 1-6.

[9] Ayoola PB and Adeyeye A. Phytochemical and nutrient evaluation of Carica papaya (pawpaw) leaves. Int J Res Rev Appl Sci. 2010; (5): $325-8$.

[10] Canini A, Alesiani D, Arcangelo GD, Tagliatesta P. Gas chromatography mass spectrometry analysis of phenolic compounds from Carica papaya L. leaf. J. Food Compos. Anal., 2007; (20): 584-590.

[11] Venkateshwarlu E, Dileep P, Rakesh KRP, Sandhya P. Evaluation of antidiabetic activity of Carica papaya seeds on streptozotocininduced type-II diabetic rats. J Adv Scientific Res, 2013; 4(2): 38 41.

[12] Juárez-Rojop IE, Díaz-Zagoya JC, Ble-Castillo JL, MirandaOsorio PH, Castell-Rodríguez AE, Tovilla-Zárate CA, RodríguezHernández A, Aguilar-Mariscal H, Ramón-Frías T, BermúdezOcaña DY. Hypoglycemic effect o

[13] f Carica papaya leaves in streptozotocin-induced diabetic rats. BMC Complement Altern Med. 2012; 28 (12): 236.

[14] Gbolade AA. (2009). Inventory of antidiabetic plants in selected districts of Lagos State, Nigeria. J Ethnopharmacol, 2009; (121): 135-139.

[15] Corral-Aguayo RD, Yahia EM, Carrillo-López A, GonzálezAguilar G. Correlation between some nutritional components and the total antioxidant capacity measured with six different assays in eight horticultural crops. J Agric Food Chem. 2008; (56): 10498 10504.

[16] Singh VK, Jasiwal P, Kumar P, Single OK. Carica papaya Linn: A potential source for various health problems. Journal of Pharmacy Research, 2010; 3(5): 998 - 1003.

[17] Isela EJ, Carlos AT, Dora EA, Luis FR, Carlos EL, Jorge LB, Leonor L, Juan CD, Deysi YB. Phytochemical screening and hypoglycemic activity of Carica papaya leaf in streptozotocininduced diabetic rats. Rev Bras Farmacogn, 2014; (24): 341-347.

[18] Owoyele BV, Adebukola OM, Funmilayo AA, Soladoye AO. Anti-inflammatory activities of ethanolic extract of Carica papaya leaves. Inflammopharmacol. 2008; (16): 168-173.

[19] Ogbe FMD, Eruogunn OL, Wagboe M. Plants Used for Female Reproductive Healthcare in Oredo Local Government Area, Nigeria. Scientific Research and Essays, 2009; (4): 120-130.

[20] Hutchison J and Dalziel JM. Flora of West Tropical Africa. Vol. II, Crown Agents for Overseas Government and Administration, London, 1963; 435-436.

[21] Usman H and Osuji J. Phytochemical and in vitro antimicrobial assay of the leaf extract of Newbouldia laevis. Afri. J. Trad. Compl.Alternat. Med., 2007; 4(4): 476-480.

[22] Iwu MM. Handbook of Africa Medicinal Plants CRC Press, Inc. London 2000; 19.

[23] Akunyili DN. Anticonvulsant Activity of the Ethanol Extract of Newbouldia laevis. Proceedings of the 2nd NAAP Scientific Conference, Zaria, 2000, 155-158.

[24] Burkil H. The Useful Plants of West Tropical Africa. Royal Botanic Gardens; Kew. DelRaso, N., Foy, B., Gearhart, J., Frazier J. (2003) Cadmium uptake kinetics in rat hepatocytes: correction for albumin binding. Toxicological Sciences. 2004; 72(1):19-30.
[25] Oliver-Bever B. Medicinal plants in Tropical West Africa. Cambridge University Press, Cambridge, 1986; 117-168.

[26] Burkill HM. The useful plants of West Tropical Africa. 2nd Edition, Vol. 4 (Families M-R), Royal Botanic Gardens, Kew. 1997.

[27] Ogunlesi M, Okiei W, Ofor E, Awonuga O. Determination of the Concentration of Zinc and Vitamin C in Oysters and Some Medicinal Plants Used to Correct Male Factor Infertility. Journal of Natural Products, 2009; (2): 89-97.

[28] Klotoe JR, Dougnon TV, Koudouvo K, Ategbo JM, Koko F, Akoegninou A, Aklikokou K, Dramane K, Gbeassor M. Ethnopharmacological Survey on Antihemorrhagic Medicinal Plants in South of Benin. European Journal of Medicinal Plants, 2013; (3): 40-51.

[29] Owolabi OJ, Amaechina FC, Okoro M. Effect of ethanol leaf extract of Newbouldia laevis on blood glucose levels of diabetic rats. Tropical Journal of Pharmaceutical Research, 2011; (10): 249-254.

[30] Osigwe CC, Akah PA, Nworu CS, Okoye FBC. Apigenin: A Methanol Fraction Component of Newbouldia laevis Leaf, as a Potential Antidiabetic Agent. The Journal of Phytopharmacology, 2017; (6): 38-44.

[31] Eyong KO, Folefoc GN, Kuete V, Beng VP, Krohn K, Hussain H, Nkeng-fack AE, Saeftel M, Sarite SR, Hoerauf A. Newbouldia quinone A: A Naphtoquinone-Anthraquinone Ether Coupled Pigment as a Potential antimicrobial and Antimalarial Agent from Newbouldia laevis. Phytochemistry, 2006; (67): 605- 609.

[32] Amos S, Binda L, Vongtau H, Chindo B, Abbah J. Sedative Effects of the Methanolic Leaf Extract of Newbouldia laevis in Mice and Rats. Bollettino Chimico Farmaceutico, 2002; (141): 471-475.

[33] Ainooson GK, Woode E, Obiri DD, Koffour GA. Antinociceptive Effects of Newbouldia laevis (P. Beauv) Stem Bark Extract in a Rat Model. Pharma-cognosy Magazine, 2009; (5): 49-54.

[34] Hassan SW, Salawu K, Ladan MJ, Hassan LG, Umar RA, Fatihu MY. Hepato-Protective, Antioxidant and Phytochemical Properties of Leaf Ex-tracts of Newbouldia laevis. International Journal of PharmTech Research, 2010; (2): 573-584.

[35] Ifegwu NO, Anibeze CIP, Ndukwe GU, Njoku-Oji NN, Agbai JU, Opara JK, Asebioyo SK. Hepatoprotective potential of ethanolic leaf extracts of Carica papaya and Newbouldia laevis on alloxaninduced diabetic wistar rats. International Journal of Multidisciplinary Research and Development. 2019; 4 (6): 38-42.

[36] Kuete V, Wabo HK, Eyon KO, Feussi MT, Wiench B, Krusche B, Effert T. Anticancer Activities of Six Selected Natural Compounds of Some Cameroonian Medicinal Plants. PLoS ONE, 2011; 6 (8): e21762.

[37] Awemu GA, Okunrobo LO, Awah FM. Wound Healing and Antiulcer Activities of the Ethanol Extract of Newbouldia laevis Root Bark. Journal of Pharmacy \& Bioresources, 2012; (9): 29-33.

[38] Szudelski T. The mechanism of Alloxan and Streptozotocin actions in $\beta$-cell of the rats' pancreas. Physiol Res 2001; 50(6): 536-546

[39] Adenowo AF, Ilori MF, Balogun FO, Kazeem MI. Protective effect of ethanol leaf extract of Carica papaya linn (Caricaceae) in alloxan-induced diabetic rats. Tropical Journal of Pharmaceutical Research. 2014; 13(11): 1877-1882

[40] Hoff J. and Rlagt L. V. Methods of blood collection in the mouse. Lab animals. 2000; 29:47-53.

[41] Loeken MR. A new role for pancreatic insulin in the male reproductive axis. Diabetes. 2012; (61): 1667-1668.

[42] Schoeller EL, Albanna G, Frolova AI, Moley KH. Insulin rescues impaired spermatogenesis via the hypothalamic-pituitary-gonadal axis in Akita diabetic mice and restores male fertility. Diabetes. 2012; 61(7):1869-1878.

[43] Schoeller EL, Schon S, Moley KH. (2012). The effects of type 1 diabetes on the hypothalamic, pituitary and testes axis. Cell and tissue research, 2012; 349 (3): 839-847.

[44] Danilova IG, Sarapultsev PA, Medvedeva SU, Gette IF, Bulavintceva TS, Sarapultsev AP. Morphological Restructuring of 
Myocardium During the Early Phase of Experimental Diabetes Mellitus. Anat Rec. 2014; 298 (2): 396-407.

[45] Loreto D and Elina V. Experimental surgical models in the laboratory rat. Boca Raton: CRC Press. 2009.

[46] Sabrina Felson. Low Testosterone and Your Health. WebMD. 2021. https://www.webmd.com/men/what-low-testosterone-can-meanyour-health

[47] Porte D, Jr, Baskin DG, Schwartz MW. Insulin signaling in the central nervous system: a critical role in metabolic homeostasis and disease from C. elegans to humans. Diabetes. 2005; (54):1264-1276.

[48] Udeh E. Nkeiruka and Nwaehujor O. Chinaka. Anti-fertility Effects of Carica papaya Linn: Methanol Leaf Extracts in Male Wistar Rats. Journal of Pharmacology and Toxicology, 2013; (8): 35-41.

[49] Akinloye OO and Morayo OM. Evaluation of andrological indices and testicular histology following chronic administration of aqueous extract of Carica papaya leaf in Wistar rat. Afr. J. Pharm. Pharmacol., 2010; (4): 252-255.

[50] Edeoga HO, Okwu DE, Mbaebie BO. Phytochemical constituents of some Nigeria medicinal plants. Afr J Biotechnol; 2005; (4): 685-688.

[51] Yakubu MT, Akanji MA, Oladiji AT. Aphrodisiac potentials of the aqueous extract of Fadogia agrestis (Schweinf. Ex Hiern) stem in male albino rats. Asian J Androl, 2005; 7: 399-404.

[52] Browning R, Schrick FN, Thompson FW, Wakefield T. Reproductive hormonal responses to ergotamine and ergonovine in cows during the luteal phase of the estrous cycle. Journalof Animal Sciences, 1998; (76): 1448-1454.

[53] Bianco F, Basini G, Grasselli F. The plant alkaloid Sanguinarine affects swinegranulose cell activity. Reproductive Toxicology, 2006; (21): 335-340.

[54] Enye LA, Edem E, Gonaka G, Ekundina VO, Akingbade M, Adefisayo, M. The effect of Newbouldia laevis on wistar rat's testis and liver histomorphology in cadmium-induced testicular toxicity and hepatotoxicity. World Journal of Pharmacy and Pharmaceutical Sciences, 2015; 4 (11): 100 - 108.

[55] Ataman JE, Osinubi AAA, Baxter-Grillo D. Cytoarchitectural effects of ethanolic leaf extract of Newbouldia laevis (P. Beauv.) on cisplatin-induced testicular damage in wistar rats. Annals of Biochemical Sciences, 2015; 14(1) 37-50.

[56] Akomolafe SF, Oboh G, Akindahunsi AA, Akinyemi AJ, Adeyanju O. Inhibitory effect of aqueous extract of Moringa oleifera and Newbuoldia laevis leaves on ferrous sulphate and sodium nitroprusside induced oxidative stress in rat's testes in vitro. Open Journal of Medicinal Chemistry, 2012; 2 (4): 1-10.

[57] Akomolafe SF, Oyeleye SI, Olasehinde TA, Oboh G. Phenolic characterization, antioxidant activities, and inhibitory effects of Physalis angulata and Newbouldia laevis on enzymes linked to erectile dysfunction. International Journal of food properties, 2018; 21 (1): 645-654.

[58] Egba S, Sunday G, Anaduaka EG. The effect of oral administration of aqueous extract of Newbouldia laevis leaves on fertility hormones of male albino rats. IOSR Journal of Pharmacy and Biological Sciences (IOSR-JPBS), 2014; 9 (3) I: 61-64. 